\title{
FREE
ACCESS \\ Variation of bowhead whale progesterone concentrations across demographic groups and sample matrices
}

\author{
Nicholas M. Kellar ${ }^{1, *}$, Jennifer $\operatorname{Keliher}^{1}{ }^{,}$Marisa L. Trego ${ }^{1,2}$, Krista N. Catelani $^{1,2}$, \\ Cyd Hanns $^{3}$, J. C. 'Craig' George ${ }^{3}$, Cheryl Rosa ${ }^{3}$ \\ ${ }^{1}$ Protected Resources Division, Southwest Fisheries Science Center, National Marine Fisheries Services, \\ National Oceanic and Atmospheric Administration, 8901 La Jolla Shores Dr., La Jolla, California 92037, USA \\ ${ }^{2}$ Ocean Associates, 4007 N. Abingdon St., Arlington, Virginia 22207, USA \\ ${ }^{3}$ North Slope Borough, Department of Wildlife Management, PO Box 69, Barrow, Alaska 99723, USA
}

\begin{abstract}
Bowhead whale Balaena mysticetus progesterone concentrations were measured in different sample matrices (serum, blubber, and urine) to investigate (1) concordance among sample type and (2) variation among life-history class. Samples were collected from subsistencehunted whales $(\mathrm{n}=86)$ taken from 1999 to 2009. In general, irrespective of sample matrix, pregnant females had the highest concentrations by orders of magnitude, followed by mature animals of both sexes, and subadults had the lowest concentrations. Subadult males and females had similar progesterone concentrations in all sample matrices measured. When pregnant animals were included in our analyses, permuted regression models indicated a strong positive relationship between serum and blubber progesterone levels $\left(r^{2}=0.894, p=0.0002\right)$. When pregnant animals were not included, we found no significant relationship between serum and blubber levels $\left(r^{2}=0.025, p=0.224\right)$. These results suggest that progesterone concentrations are mirrored in these sample types over longer periods (i.e. on the order of weeks to months, time frame of reproductive changes) but not shorter periods (i.e. on the order of hours to days, time frame of daily fluctuations). This conclusion is consistent even for progesterone concentrations measured in females that had recently changed pregnancy states (either new mothers or newly pregnant animals), for which blubber progesterone levels seem to lag those in the serum. Finally, urine progesterone had statistically significant positive relationships with serum $\left(r^{2}=0.136, p=0.0460\right)$ and blubber progesterone $\left(r^{2}=0.150, p=0.0421\right)$. Our results suggest that progesterone concentrations first peak in the serum, then in the urine, and finally in the blubber.
\end{abstract}

KEY WORDS: Bering Sea $\cdot$ Chukchi Sea $\cdot$ Beaufort Sea $\cdot$ Balaena mysticetus $\cdot$ Pregnancy $\cdot$ Blubber $\cdot$ Urine $\cdot$ Serum

\section{INTRODUCTION}

During the second half of the 19th century, commercial whaling substantially depleted the BeringChukchi-Beaufort Sea (BCB) stock of bowhead whales Balaena mysticetus. However, since that time, increasing abundance trends provide evidence of an ongoing recovery (George et al. 2004). The whales have a predicted breeding season centered in March that extends into April (Reese et al. 2001), and gestation is estimated to be 14 mo (90\% prediction interval: 13 to $15.2 \mathrm{mo}$ ). These animals represent a valuable subsistence resource for Alaskan Native subsistence consumers, who find hunting opportunities during the whales' yearly migrations between the Bering and Beaufort Seas. Biological samples from bowhead 
whales landed during the spring and fall hunts are often collected by researchers and yield diverse sets of tissue matrices such as major organs, skin, serum, blubber, urine, baleen, reproductive tissues, and other tissues. These samples have been used in a number of studies investigating different aspects of the biology of these animals (Rosa et al. 2007a,b, 2008, Budge et al. 2008), yet more can be gleaned from this material, including information about bowhead reproductive endocrinology. By measuring hormone concentrations across multiple sample matrices (blood, urine, and blubber) from these harvested animals, the present study aims to expand knowledge of bowhead whale biology and provide baseline values that researchers can use for purposes of comparison as this species continues to respond to changes including exposure to new perturbations in their arctic habitat.

In addition to providing baseline endocrine information, this investigation adds to an emerging research practice in cetology that uses blubber tissue collected from projectile biopsies to assess the health and reproductive status of cetacean populations. These samples are collected from specialized darts that retain small $(\sim 6 \times 15 \mathrm{~mm})$ cores of the epidermis and distal dermis (blubber) layers of the skin (reviewed by Noren \& Mocklin 2012). They are the biological samples most frequently collected from freeranging cetaceans and are often obtained in numbers suitable for estimates of population-level demographic parameters. Recently, a number of studies have begun measuring steroid hormones from blubber tissue in efforts to glean additional biological information from these samples (Kellar et al. 2006, 2009, Amaral 2010, Pérez et al. 2011). In particular, progesterone, the hormone responsible for sustaining gestation, found in blubber samples has been empirically accurate at differentiating/diagnosing pregnancy state (Mansour et al. 2002, Kellar et al. 2006, Pérez et al. 2011).

However, the bulk of mammalian endocrine literature reports steroid hormone levels from blood (Temte 1991, Kjeld et al. 1992, 2004, Atkinson et al. 1999) and to a lesser degree urine (Robeck et al. 1993), feces (Rolland et al. 2005, 2006), and saliva (Atkinson et al. 1999, Hogg et al. 2005). Other sample materials from which these hormones have been extracted and measured include milk (West et al. 2000), muscle (Yoshioka et al. 1994), cetacean exhalant or blow (Hogg et al. 2005), bone, and ocular secretions (Atkinson et al. 1999). Only a scant few studies have measured reproductive hormones from adipose tissue of any kind, let alone blubber (Hillbrand \& Elsaesser 1983, Hamudikuwanda et al. 1996, Mansour et al.
2002, Kellar et al. 2006), though one of these does include data from minke whales Balaenoptera acutorostrata, a species of baleen whale (Mansour et al. 2002). Consequently, the relationships between hormone levels and their specific effects on mammalian biology have not been delineated for blubber tissue, and because this tissue is very different in chemistry, structure, and dynamics from these more commonly used matrices, we would not necessarily expect to find a simple relationship between blubber hormone concentrations and concentrations obtained from more routinely measured matrices.

There are 2 ways to potentially overcome this research deficit. One is to continue to amass hormone values from cetaceans representing as many biological conditions as possible, thereby creating a blubber-specific reference value collection. This will happen slowly through the natural process of scientific discovery, including through the results from the present study. The second way is to find quantitative relationships between levels found in the blubber and those found in the other matrices so that the value from one matrix can be used to accurately estimate the values for the other matrices. Here, we attempt to further both of these approaches by comparing progesterone levels across 3 sample matrices (blood, urine, and blubber) from harvested bowhead whales representing 5 different demographic groups.

\section{MATERIALS AND METHODS}

\section{Samples}

Serum, blubber, and urine samples were collected from bowhead whales harvested near Barrow, Savoogna, Kaktovik, and Wainwright villages from 1999 to 2009 during the spring and fall Inuit subsistence hunts in Alaska. These collections were conducted under the auspices of the Barrow Whaling Captain's Association and the Alaska Eskimo Whaling Commission through the Department of Wildlife Management (North Slope Borough, Alaska) in accordance with National Oceanic and Atmospheric Administration permits (\#932-1489-00 and 932-1489-03 for the Marine Mammal Health and Stranding Program program issued to Dr. Teri Rowles). Morphometric data and reproductive information including pregnancy status, number of corpora, corpus luteum size, and the length of fetus (if present) were collected simultaneously with the majority of the samples. Age measurements were not available for these animals, and as such, maturity designation was based on total 
length, an established practice to separate demographic classes. The length boundaries between maturity states used in the present study were $13.35 \mathrm{~m}$ and $12.5 \mathrm{~m}$ for females and males respectively (Koski et al. 1993, George et al. 2011).

Blood was collected approximately 2 to $14 \mathrm{~h}$ postmortem ${ }^{1}$ from the palatal sinus of 67 bowhead whales into untreated evacuated 'red top' tubes (Vacutainer/ $\mathrm{BD})$. The blood was allowed to clot and then centrifuged for $10 \mathrm{~min}$ at $3500 \times g$ within 4 to $6 \mathrm{~h}$ of collection (blood was kept at $5^{\circ} \mathrm{C}$ during the holding period). The serum was transferred by pipette to a $5 \mathrm{ml}$ plastic culture tube and frozen at $-20^{\circ} \mathrm{C}$ then archived at $-80^{\circ} \mathrm{C}$ until thawed for hormone analyses.

Blubber samples were obtained from the region $\sim 1 \mathrm{~m}$ posterior to the blowhole in 70 individual whales: 42 male and 28 female. The samples were stored at $-20^{\circ} \mathrm{C}$ or lower until further subsampling occurred. Cross-sectional subsamples (250 mg; approximately the amount obtained by a large biopsy), were taken from epidermis to $\sim 2 \mathrm{~cm}$ below the epidermal/dermal boundary for laboratory processing. The columns of blubber were weighed and then placed into homogenization tubes.

Most urine samples were collected by sterile needle aspiration into a sterile syringe as soon as the bladder was seen during butchering. Occasionally, the bladder was cut with a knife, and urine was caught in a tube. The 28 urine samples were allowed to freeze and stored frozen at $-20^{\circ} \mathrm{C}$.

\section{Serum and urine progesterone isolation}

For all serum samples, a steroid-displacement reagent (Enzo Life Sciences) was added (1:99 reagent to sample ratio) to decouple steroid-binding proteins. Both urine and serum samples were diluted with phosphate-buffered saline (PBS, pH 7.5 with $1 \%$ bovine $\gamma$-globulin) and then placed directly into the enzyme immunoassay (EIA) for measurement (see 'Progesterone enzyme immunoassay'). If a sample was measured below detection limits, progesterone was extracted from $1.0 \mathrm{ml}$ of the sample twice with $1.0 \mathrm{ml}$ of diethyl ether, then evaporated under nitrogen gas, and finally reconstituted in $250 \mu \mathrm{l}$ of PBS.

\footnotetext{
${ }^{1}$ It should be noted that though progesterone is often considered robust, i.e. resistant to chemical breakdown, the levels especially in the blood may have altered somewhat before they were sampled. However, given the very cold environment from which these animals where harvested, the process of breakdown was likely slow
}

\section{Blubber progesterone isolation}

The blubber hormone extractions followed the methods delineated by Kellar et al. (2006) with several modifications to simply the procedure and increase consistency. Approximately $0.5 \mathrm{~g}$ of blubber was homogenized 7 to 9 times at a speed of $5 \mathrm{~m} \mathrm{~s}^{-1}$ for $45 \mathrm{~s}$ intervals depending on sample consistency. An aliquot of $500 \mu$ l of the homogenate was combined with $2 \mathrm{ml}$ of 4:1 ethanol:acetone. The resulting solution was vortexed and then centrifuged at $4500 \times g$ for $15 \mathrm{~min}$. The supernatant was transferred and evaporated. Two $\mathrm{ml}$ of diethyl ether were added, vortexed, and centrifuged again. The supernatant was collected and evaporated, the residue was resuspended in $1000 \mu \mathrm{l}$ of acetonitrile and vortexed, and $1000 \mu \mathrm{l}$ of hexane were added to the mixture. After the solution was vortexed and centrifuged again, the acetonitrile layer was aspirated into a new tube, and the process was repeated with another $1000 \mu \mathrm{l}$ of hexane. The final portion of acetonitrile was collected and evaporated. The remaining residue was centrifuged at $4500 \times g$ for $5 \mathrm{~min}$ and stored at $-20^{\circ} \mathrm{C}$.

\section{Progesterone enzyme immunoassay}

To prepare the samples for the EIA, they were suspended in varying amounts of PBS. To make measurements in an accurate detection range on the EIA, samples from non-pregnant individuals were resuspended in $250 \mu \mathrm{l}$ of PBS, and samples from those that were pregnant were resuspended in $1000 \mu \mathrm{l}$; then, the samples were vortexed in a multitube vortexer for $15 \mathrm{~min}$. Each sample was individually vortexed prior to quantifying progesterone concentration. We used EIA kit 900-011 (Enzo Life Sciences), which has $100 \%$ reactivity with progesterone and $5 \alpha$-Pregnane-3, 20-dione in each sample. The assay control limits were between 15 and $500 \mathrm{pg} \mathrm{ml}^{-1}$ with a sensitivity of $8.57 \mathrm{pg} \mathrm{ml}^{-1}$. Sample measurements that exceeded this range had to be diluted further to be accurately measured. These samples were diluted at 1:100, 1:20, 1:5, 1:3, and 1:2 depending on their original EIA measurements such that the final measurements would fall within the range of the control samples. Assay standards were run in duplicate, and samples were extracted and measured in triplicate. The intra-assay coefficient of variation $(\mathrm{CV})$ was between $4.9 \%$ and $7.6 \%$, and an inter-assay CV was between $2.7 \%$ and $6.8 \%$. Triplicate samples with $>33.3 \%$ CV were extracted and measured again from original tissue. Three sets of 
single control doses (in duplicate) were run with each assay at the beginning, middle, and end of each EIA plate. Demographic groups that were compared in the present study were randomly assigned to extraction sets and EIA measurement plate positions using random number assignments created in Excel (Microsoft).

We determined the extraction efficiency using spiked samples according to Kellar et al. (2006). These extraction control samples were spiked with 0 , 10 , and $30 \mathrm{ng}$ of $\mathrm{P} 4$. The percentage of $\mathrm{P} 4$ that was recovered after extraction was calculated, and each assay value was adjusted to the standard prior to analysis. The resulting measurements of extraction efficiency were $67.3 \%(\mathrm{SE}=6.11 \%)$ and $72.1 \%(\mathrm{SE}=$ $9.09 \%$ ) for the 10 and $30 \mathrm{ng}$ levels respectively.

\section{Creatinine enzyme immunoassay}

For all urine samples, measured progesterone concentrations were corrected for creatinine content (i.e. $\mathrm{ng}_{\text {progesterone }}$ per $\mathrm{g}_{\text {creatinine) }}$. To assess creatinine concentrations, we used a Jaffe reaction-based colorimetric detection kit (907-030A, Enzo Life Sciences) following the manufacturer's instructions. The assay control limits were between $0.325 \mathrm{mg} \mathrm{dl}^{-1}$ and $20 \mathrm{mg}$ $\mathrm{dl}^{-1}$ with a sensitivity of $0.042 \mathrm{mg} \mathrm{dl}^{-1}$. All samples were initially diluted at 1:20 and then diluted further if their measurements fell above the $80 \%$ range of the standard curve. No values were observed below the lower $20 \%$ range of the standard curve. Assay standards and samples were run in duplicate. Duplicate samples with $>33.3 \%$ CV were measured again from dilution of original sample and then averaged across all samples until the CV was $<33.3 \%$.

\section{Parallelism and matrix effects analyses}

We conducted 2 additional quality control assessments to gauge the performance of using the blubber extracts with the progesterone EIA kit. The first was a parallelism test in which a serially diluted pool sample was run with the standard controls of the assay to assess whether the linear decrease in measured values of the pooled sample was parallel to the standard curve. Ten individuals composed of 1 pregnant and 9 non-pregnant individuals were pooled together to obtain a representative sample across our bowhead samples. The 10 pooled sample concentrations were made by diluting from the undiluted preparation to $1 / 500$ decreasing by a factor of 2 . Each dilution was run twice then compared to the standard curve.

The second quality assessment examined the potential effect of the blubber extract on the measurement data. Here, 5 EIA standard curves were assayed: (1) without spiking, (2) spiking each standard with PBS at 1:4 (PBS:standard), and (3 to 5) spiking each standard with a pooled sample (also composed of 10 individuals but none pregnant ${ }^{2}$ ) at dilutions of 1:4 (pooled sample:standard), 1:9:40 (pooled sample: PBS:standard), or 1:99:400 (pooled sample:PBS:standard) respectively. The difference between the expected concentration (PBS:standard curves) and the measurement from the pooled extract-spiked sample curves, once the progesterone added by the pooled extract-spiked sample itself was factored out, represents the effect of the matrix on the assay.

\section{Statistical analysis}

All statistical analyses were performed using MATLAB R2009b (Mathworks). To compare concentrations of different demographic groups, progesterone

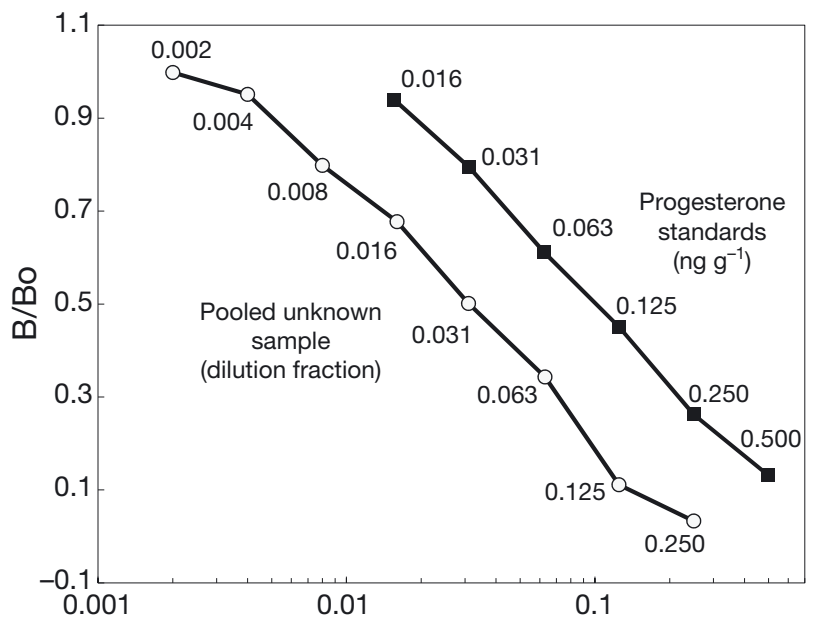

Fig. 1. Linearity assessment of progesterone enzyme immunoassays (EIA) with bowhead whale (Balaena mysticetus) blubber tissue. (O) Serial dilutions of extracts show parallelism with ( $\square$ ) the standards of the progesterone EIA, an indication that the assay is measuring the same antigens in the blubber as in the standards and is therefore suitable for use with the blubber tissue. Ten individuals were represented in the pooled unknown sample, including 9 immature and 1 non-pregnant mature female

\footnotetext{
2No pregnant animals were used in this pool because we felt that the ratio of progesterone from a pregnant individual would overwhelm any signal from the other demographic groups
} 
measurements were analyzed using the differencesof-means permutation test (Manly 1991) (comparable to Student's $t$-test but does not require that parametric assumptions are met) where null comparison distributions were generated by permuting (10000 iterations) the observed progesterone values while holding the demographic designations constant. To assess the relationships between concentrations in each of the sample matrices, permuted regression analyses were employed via MATLAB's general linear model framework, holding one set of values constant and then permuting the other matrix's values to generate each set of null model comparison values. The slope from the observed, non-permuted linear model was then compared against the resulting distribution of slope values generated by the 10000 permutation runs. The p-values were then generated based on which quantile contained the observed value within the distribution of slope values generated from the permutation runs.

Table 1. Results from matrix interference assessment. Assay standards (Std) were spiked with either phosphate-buffered saline (PBS) or a set of serial dilutions of a pooled sample (Pool) composed of extracts from 10 bowhead whale (Balaena mysticetus) individuals. The concentration of progesterone contributed from the pooled sample (undiluted $=138.9 \pm 7.6 \mathrm{ng} \mathrm{g}^{-1}$ ) was subtracted from each sample-spiked measurement so its contribution would be factored out of the assessment

\begin{tabular}{|c|c|c|c|c|c|c|}
\hline \multirow{3}{*}{$\begin{array}{l}\text { PBS:Std } \\
\left(\mathrm{ng} \mathrm{g}^{-1}\right) \\
\text { Mean } \pm \text { SE }\end{array}$} & \multicolumn{2}{|c|}{ 1:4 (Pool:Std) } & \multicolumn{2}{|c|}{ 1:9:40 (Pool:PBS:Std) } & \multicolumn{2}{|c|}{ 1:99:400 (Pool:PBS:Std) } \\
\hline & $\left(\mathrm{ng} \mathrm{g}^{-1}\right)$ & $\%$ of & $\left(\mathrm{ng} \mathrm{g}^{-1}\right)$ & $\%$ of & $\left(\mathrm{ng} \mathrm{g}^{-1}\right)$ & $\%$ of \\
\hline & Mean \pm SE & PBS:Std & Mean \pm SE & PBS:Std & Mean \pm SE & PBS:Std \\
\hline $391.6 \pm 27.0$ & $352.4 \pm 4.9$ & 90.0 & $358.0 \pm 8.8$ & 91.4 & $398.0 \pm 11.0$ & 101.6 \\
\hline $194.2 \pm 0.1$ & $160.3 \pm 1.6$ & 82.5 & $189.6 \pm 2.8$ & 97.7 & $191.6 \pm 8.1$ & 98.7 \\
\hline $97.9 \pm 4.7$ & $77.7 \pm 3.1$ & 79.3 & $89.7 \pm 5.5$ & 91.5 & $99.2 \pm 0.9$ & 101.3 \\
\hline $45.5 \pm 0.8$ & $36.2 \pm 1.2$ & 79.7 & $41.5 \pm 0.7$ & 91.3 & $44.8 \pm 1.1$ & 98.6 \\
\hline $23.1 \pm 2.3$ & $20.4 \pm 3.3$ & 88.4 & $23.2 \pm 3.4$ & 100.2 & $23.2 \pm 4.4$ & 100.2 \\
\hline Mean \% & & 84.0 & & 94.4 & & 100.1 \\
\hline
\end{tabular}

Table 2. Balaena mysticetus. Mean bowhead whale progesterone concentrations in 3 different sample matrices across various demographic groups. Asterisks indicate significant differences $(p<0.05)$ between the mean value and mean value of the row above

\begin{tabular}{|c|c|c|c|c|c|c|}
\hline \multirow{2}{*}{$\begin{array}{l}\text { Reproductive } \\
\text { group }\end{array}$} & \multicolumn{2}{|c|}{ Serum (pg ml $\left.{ }^{-1}\right)$} & \multicolumn{2}{|c|}{ Blubber $\left(\mathrm{ng} \mathrm{g}^{-1}\right)$} & \multicolumn{2}{|c|}{ Urine (ng g ${ }^{-1}$ creatinine) } \\
\hline & $\mathrm{n}$ & Mean $\pm \mathrm{SE}$ & $\mathrm{n}$ & Mean $\pm \mathrm{SE}$ & $\mathrm{n}$ & Mean \pm SE \\
\hline \multicolumn{7}{|l|}{ Female } \\
\hline Immature & 21 & $38.1 \pm 6.9$ & 19 & $0.41 \pm 0.06$ & 14 & $239.8 \pm 84$ \\
\hline $\begin{array}{l}\text { Mature } \\
\text { non-pregnant }\end{array}$ & 2 & $104.9 \pm 45.0$ & 3 & $7.12 \pm 3.4^{*}$ & - & - \\
\hline Pregnant & 2 & $31587 \pm 28057^{*}$ & 6 & $15.70 \pm 1938^{*}$ & - & - \\
\hline \multicolumn{7}{|l|}{ Male } \\
\hline Immature & 32 & $41.9 \pm 4.8$ & 30 & $0.52 \pm 0.05$ & 13 & $167.8 \pm 33$ \\
\hline Mature & 10 & $55.8 \pm 7.2$ & 12 & $1.43 \pm 0.25^{*}$ & 1 & 315.8 \\
\hline
\end{tabular}

\section{RESULTS}

The results of the parallelism assessment are depicted in Fig. 1. Serial dilutions of the pooled blubber extract demonstrate parallel measurements when compared to the assay standards; stepwise bootstrap slope calculations of the observed vs. expected relationship in the pooled extra were not significantly different from 1 (median $=1.01,95 \% \mathrm{CI}=0.96-1.08$; $\mathrm{p}=0.706)$.

The matrix effects analysis suggests that when the ber extracts are more concentrated, they artifion average, $84.0 \%$ of the standard levels spiked with PBS. This effect decreased and was not statistically significant when the extracts are more diluted at $1: 10(94.4 \%, \mathrm{p}=$ $0.170)$ and $1: 100(100.1 \%, p=$ $0.586)$.

\section{Progesterone levels relative to demographic groups}

Table 2 summarizes the demographic-specific progesterone measurements for each sample matrix. In general, the matrices follow similar concentration patterns relative to demography. For females, we find the highest levels of progesterone in pregnant animals, substantially less in non-pregnant mature individuals, and the lowest levels in subadults (note: urine samples were only collected from subadult individuals, so demographic comparison was not possible). For males, mature animals had higher measured progesterone concentrations than subadults irrespective of sample matrix. Statistical significance as determined from the differenceof-mean permutation test is delineated in the following matrixspecific discussion sections. 
Serum progesterone

Mean serum progesterone concentrations $( \pm 1 \mathrm{SE})$ were orders of magnitudes higher in pregnant females $\left(31587 \pm 28057 \mathrm{pg} \mathrm{ml}^{-1}\right)$ than in non-pregnant females $\left(43.9 \pm 10.2 \mathrm{pg} \mathrm{ml}^{-1}, \mathrm{p}=0.0035\right)$, irrespective of maturity state. Similarly, non-pregnant mature females had significantly higher levels than subadults $\left(104.9 \pm 45.0 \mathrm{pg} \mathrm{ml}^{-1}, \mathrm{p}=0.044\right)$, though the magnitude of the difference was much less. Conversely, mature and subadult males had similar serum progesterone levels to one another $\left(38.1 \pm 6.9 \mathrm{pg} \mathrm{ml}^{-1}\right.$, $\mathrm{p}=0.167)$.

\section{Blubber progesterone}

The results for the blubber were similar to those for the serum but with greater differences among demographic groups. Again, pregnant females had by far the highest concentrations $\left(615.70 \pm 1938 \mathrm{ng} \mathrm{g}^{-1}\right)$, separated statistically from non-pregnant mature and subadult females $\left(7.12 \pm 3.4 \mathrm{ng} \mathrm{g}^{-1}, \mathrm{p}<0.0001\right.$, and $0.41 \pm 0.06 \mathrm{ng} \mathrm{g}^{-1}, \mathrm{p}=0.0113$ respectively). In addition, non-pregnant mature females had significantly higher levels than subadults $(\mathrm{p}=0.004)$. Although blubber appearred to vary relative to pregnancy state, there is no indication that it varied relative to the stage of pregnancy (i.e. early, middle, or late) (Table 3$)$. For males, mature animals $(1.43 \pm 0.25$ $\mathrm{ng} \mathrm{g}^{-1}$ ) also had significantly higher levels of progesterone than subadults $\left(0.52 \pm 0.05 \mathrm{ng} \mathrm{g}^{-1}, \mathrm{p}<0.0001\right)$. Both of these latter findings, with progesterone level differing by maturity status in both sexes, are findings unique to the present study and will be addressed further in the 'Discussion'.

Table 3. Balaena mysticetus. Bowhead blubber progesterone concentrations in individual mature females. L: lactating; P: pregnant

\begin{tabular}{|lccccc|}
\hline $\begin{array}{l}\text { Sample } \\
\text { ID }\end{array}$ & $\begin{array}{c}\text { Blubber } \\
\text { progesterone } \\
\left(\text { ng g }^{-1}\right)\end{array}$ & $\begin{array}{c}\text { Length } \\
(\mathrm{m})\end{array}$ & Sex & $\begin{array}{c}\text { Fetal } \\
\text { length } \\
(\mathrm{cm})\end{array}$ & L/P \\
\hline 01B17 & 1.59 & 13.9 & $\mathrm{~F}$ & & Neither \\
08B14 & 6.34 & 13.6 & $\mathrm{~F}$ & & Neither \\
07B10 & 13.43 & 16.1 & $\mathrm{~F}$ & & $\mathrm{~L}$ \\
99B7 & 100.78 & 15.4 & $\mathrm{~F}$ & 4 & $\mathrm{P}$ \\
99B18 & 339.73 & 13.0 & $\mathrm{~F}$ & 399 & $\mathrm{P}$ \\
00B5 & 377.24 & 19.1 & $\mathrm{~F}$ & 38 & $\mathrm{P}$ \\
07B12 & 572.99 & 14.8 & $\mathrm{~F}$ & 31 & $\mathrm{P}$ \\
07B9 & 875.28 & 14.3 & $\mathrm{~F}$ & 400 & $\mathrm{~L} / \mathrm{P}$ \\
07B16 & 1428.20 & 14.4 & $\mathrm{~F}$ & 159 & $\mathrm{P}$ \\
\hline
\end{tabular}

Urine progesterone

Given the lack of representation of various demographic groups in the urine sample set, the only demographic comparison made was between male $\left(167.8 \pm 33.0 \mathrm{ng} \mathrm{g}^{-1}\right.$ creatinine $)$ and female $(239.8 \pm$ $84.0 \mathrm{ng} \mathrm{g}^{-1}$ creatinine) subadults, which were not significantly different from each other $(p=0.462)$. This finding was true for male/female subadult comparisons in serum and blubber as well $(p=0.421$ and $\mathrm{p}=0.381$ respectively).

\section{Relationships of progesterone levels in the different sample matrices}

When pregnant females were included in the permuted regression analysis, we found a strong relationship between serum progesterone and blubber progesterone $\left(r^{2}=0.894, p=0.0002 ;\right.$ Fig. 2$)$. When they were not included, the relationship between serum and blubber was much weaker and statistically not significant $\left(\mathrm{r}^{2}=0.025, \mathrm{p}=0.224\right.$; Fig. 3). Conversely, urine progesterone had a positive relationship with both serum $\left(r^{2}=0.136, p=0.0460\right.$; Fig. 4$)$ and blubber $\left(r^{2}=0.150, p=0.0421\right.$; Fig. 5); no measurements from pregnant animals were included in this analysis as no urine was obtained from pregnant individuals.

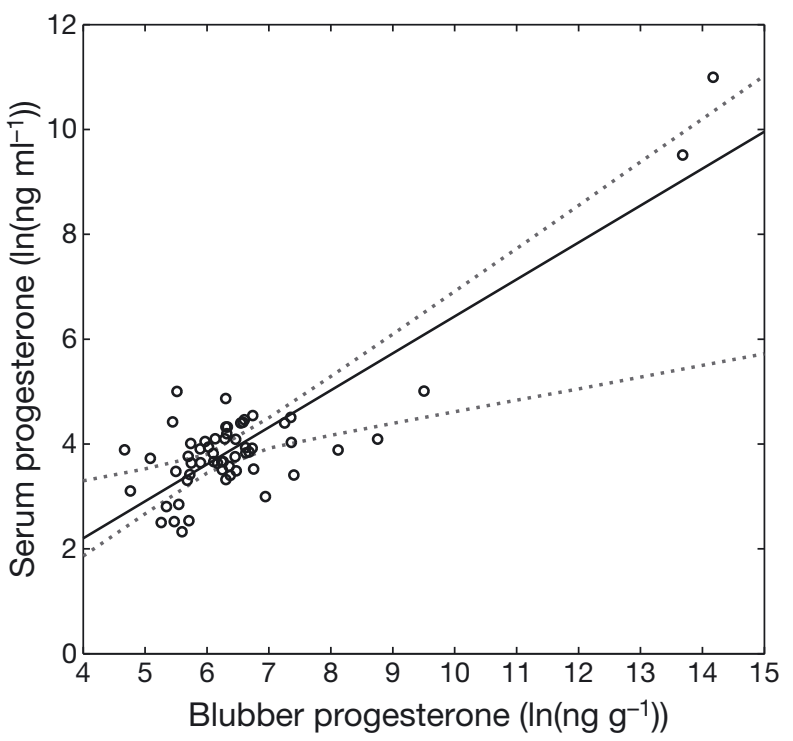

Fig. 2. Balaena mysticetus. Natural log values of serum and blubber progesterone (P4). From the slope of the permutation regression line $\ln ($ serumP4 $)=-0.618+[0.705 \times \ln ($ blubberP4)], we found a strong, significant positive relationship between progesterone values in both matrices when pregnant animals were included in the analysis. Solid line: best fit regression; dotted line: $95 \%$ confidence envelope 


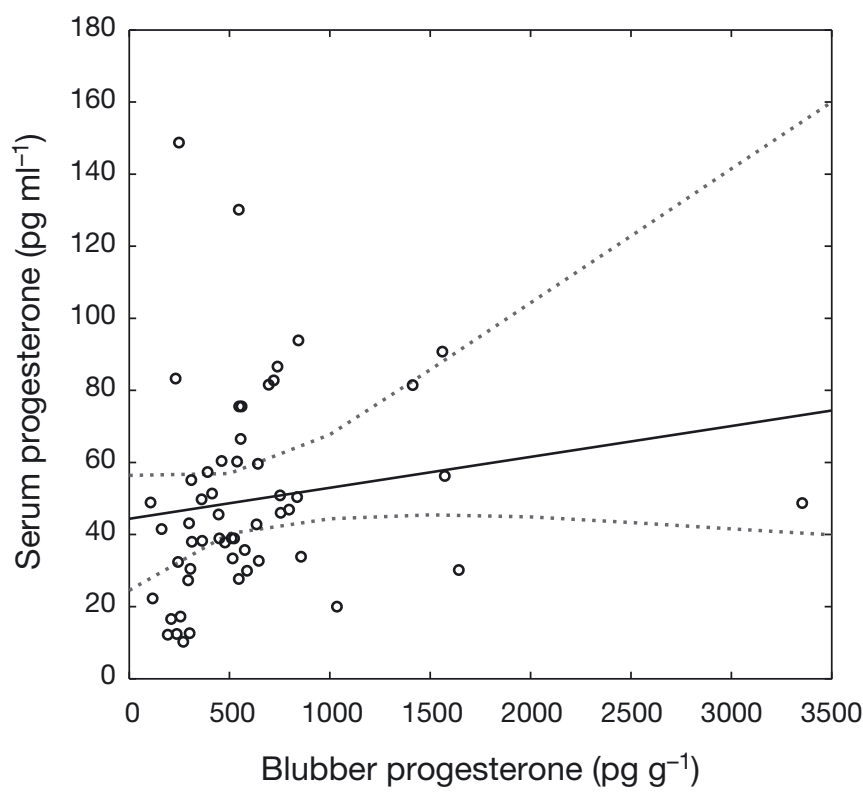

Fig. 3. Balaena mysticetus. Serum and blubber progesterone concentrations. We did not find a significant positive relationship between progesterone values in both matrices when pregnant animals were excluded $(p=0.224)$. However, the best fit regression had the form serumP $4=44.4+$ $(0.0086 \times$ blubberP4). Solid line: best fit regression; dotted line: $95 \%$ confidence envelope

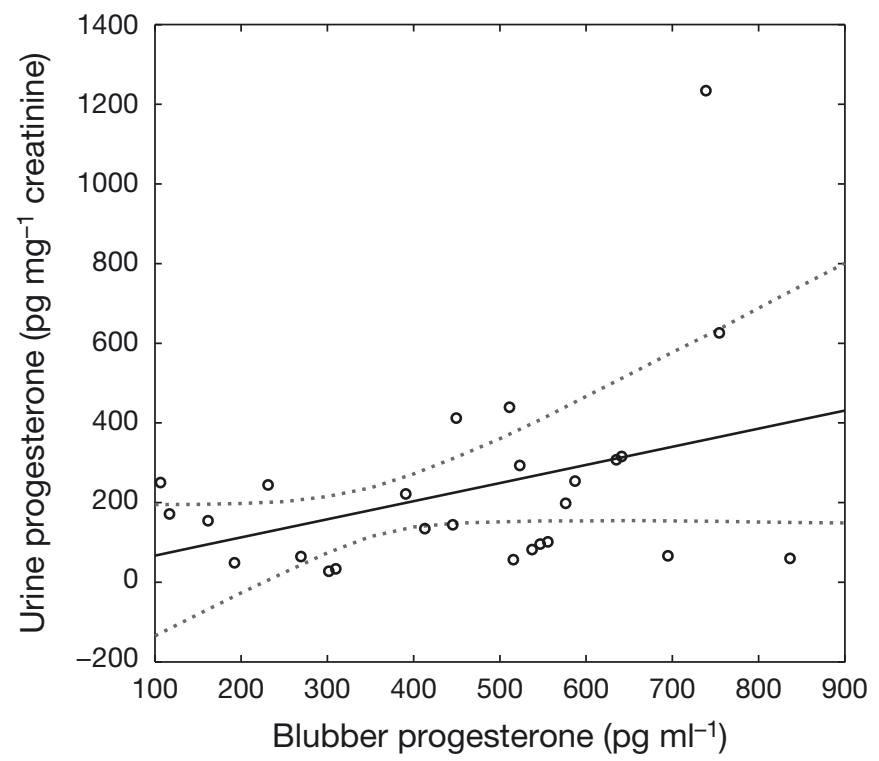

Fig. 4. Balaena mysticetus. Blubber and urine progesterone concentrations. From the slope of the regression line urineP4 $=21.4+(0.455 \times$ blubberP4 $)$, we find a significant positive relationship between progesterone values in both matrices. Solid line: best fit regression; dotted line: $95 \%$ confidence envelope

\section{DISCUSSION}

Three broad findings were revealed in the present study. First, there were large differences in progesterone concentration between pregnant and nonpregnant animals yet smaller differences, if any, in progesterone concentrations between the demographic groups comprising the non-pregnant animals (i.e. non-pregnant mature females, immature females, and males). This is consistent with other studies in the literature (see 'Progesterone levels relative to demographic groups'). Second, progesterone levels in bowhead whales were generally similar to those documented for other cetacean species irrespective of sample matrix or demographic group, with a couple of exceptions (discussed below). Third, when large differences in progesterone level were observed (i.e. those differentiating pregnant from non-pregnant individuals), the measured matrices show strong correlation to each other; however, when the differences were smaller (e.g. individual variation among immature individuals), we found weaker or non-significant relationships between the matrices. These results are consistent with a gradient in progesterone circulation dynamics in which we presume the most recently produced progesterone levels are reflected in the blood, then the urine, and then finally the blubber.

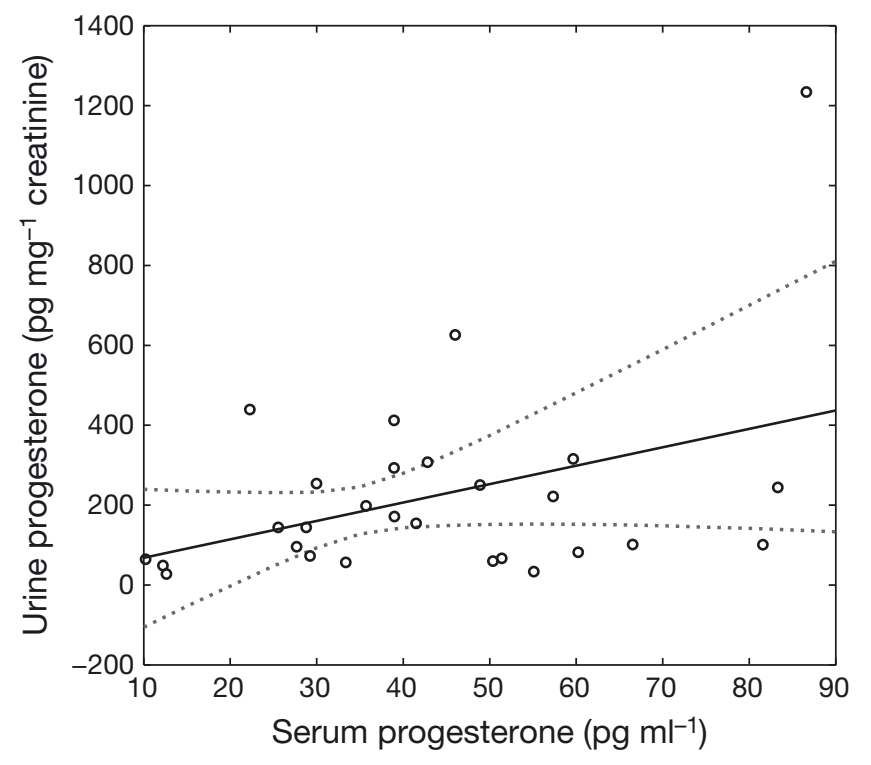

Fig. 5. Balaena mysticetus. Serum and urine progesterone concentrations. From the slope of the regression line urineP4 $=22.1+(4.61 \times$ serumP4 $)$, we find a significant positive relationship between progesterone values in both matrices. Solid line: best fit regression; dotted line: 95\% confidence envelope 


\section{Parallelism and matrix effects analyses}

The parallelism analysis demonstrated segments of the measured blubber extract curves matching the true concentrations of the standards, suggesting that the assays were binding to the same antigens in the blubber extracts as in the standards. The bootstrap slope statistical test verified the parallel nature of values, which is an important validation step of using the assay with bowhead blubber extracts. The matrix effects analysis suggested that components of the blubber extract interfered with the assay, creating statistically significant lower measurement values when the extracts were concentrated. However, as expected, this effect dissipated as the extracts were diluted. The ramification of this matrix effect is that lower progesterone values will appear even lower because samples with inherently less progesterone are assayed at higher concentrations and therefore are exposed to greater matrix effects during EIA measurements. However, the effects are very small ( $\sim 16 \%$ reduction at our most concentrated extracts, run at 1:5 dilutions) compared to the large differences between pregnancy states.

\section{Progesterone levels relative to demographic groups}

\section{Serum progesterone}

Serum progesterone levels were similar to those that were reported previously for other baleen whales. For the females, as expected, pregnant animals had much higher levels of progesterone than non-pregnant individuals. Mean progesterone levels (0.054 ng $\mathrm{ml}^{-1}$ ) in immature animals were in line with those reported in other baleen whales: minke whales Balaenoptera acutorostrata, $<0.02$ to $1.50 \mathrm{ng} \mathrm{ml}^{-1}$ (Suzuki et al. 2001, Kjeld et al. 2004, Birukawa et al. 2005); sei whales Balaenoptera borealis, $<0.04 \mathrm{ng} \mathrm{ml}^{-1}$ (Kjeld et al. 2003); and fin whales Balaenoptera physalus, $<0.04 \mathrm{ng} \mathrm{ml}^{-1}$ (Kjeld et al. 1992, Kjeld 2001). However, the mean value for the serum in the pregnant bowhead whales (31.6 $\mathrm{ng} \mathrm{ml}^{-1}$ ) in the present study was substantially higher than mean values seen in other pregnant baleen whales: minke whales, 6.71 to $13.8 \mathrm{ng} \mathrm{ml}^{-1}$ (Suzuki et al. 2001, Kjeld et al. 2004, Birukawa et al. 2005); and sei whales, 3.24 to $6.60 \mathrm{ng} \mathrm{ml}^{-1}$ (Kjeld et al. 2003, Birukawa et al. 2005). The pregnant bowhead whale values were more similar to those reported for captive killer whales Orcinus orca of 8.90 to $56.2 \mathrm{ng} \mathrm{ml}^{-1}$ (Walker et al. 1988). It is likely that different sample treatments and assay methodologies (e.g. the globulin decoupling reagent used in the present study versus these other studies, where it is unclear whether a similar reagent was used) may explain some of the vagaries in the measurements from different animals/studies. Also, species-specific differences in physiology may contribute to the different hormone levels; for instance, the large relative blubber composition of bowheads is unique among baleen whales, and this may impact the circulating levels of lipophilic hormones like progesterone.

We were unable to find progesterone serum values reported in the literature for any male cetaceans. The males we measured, irrespective of maturity state (i.e. size class), had similar serum progesterone concentrations to subadult females. The role of progesterone in male cetaceans has yet to be described, but typically it is recognized as a precursor to other steroids, and in males of some species (e.g. human, rats, and cattle), it is important for normal sexual behavior (Andersen \& Tufik 2006, Wagner 2006) and generalized stress response (Cooper et al. 1995).

\section{Blubber progesterone}

Most of the measured blubber progesterone levels, like those found in the serum, were similar to levels seen in other cetaceans (Mansour et al. 2002, Kellar et al. 2006, Pérez et al. 2011). However, the mean levels in the pregnant females were among the highest ever recorded in any cetacean, which created a separation of several orders of magnitude between pregnant and non-pregnant/immature females. This large separation is consistent with previous findings (Mansour et al. 2002, Kellar et al. 2006, Pérez et al. 2011) and suggests that blubber progesterone is useful for identifying pregnant females. However, what is unique in our results compared to these earlier studies is the significant difference in blubber progesterone concentrations between mature non-pregnant females and immature ones. This is an expected result as sexually mature female mammals circulate greater levels of progesterone for estrous regulation, especially during the luteal phase of estrual cycling (Pineda 2003). Also, it is possible that one or more of the non-pregnant mature females were harvested recently after parturition and therefore still had higher levels of progesterone in their blubber. Finally, in pubescent females, progesterone is episodically produced especially during the final phases of puberty as the hypothalamus becomes less sensitive to the negative feedback of reproductive steroids (Pineda 2003). 
The significantly higher blubber progesterone concentrations in animals greater than $12.5 \mathrm{~m}$ suggest that these concentrations are associated with sexual maturity. As with serum progesterone, little information exists regarding blubber progesterone's association with male sexual maturation. Perhaps, because progesterone is a precursor to testosterone and other androgens, the high levels of blubber progesterone are merely associated with the production of these male hormones. However, there are inconsistencies with this explanation. Serum progesterone in these males did not show a similar differentiation between demographic classes as would be expected. Additionally, we found relatively high blubber progesterone values in the adult males in both hunting seasons. Because testosterone production is highest during the breeding season, we would expect to detect higher levels in animals collected during the spring (the predicted mating period for bowhead whales) and for concentrations to return to lower levels by the fall. Stress response also may be a contributor to adrenal derived progesterone in harvested males, as in other mammalian males (Cooper et al. 1995). The stress-associated progesterone secretion is thought to be a result of rate-limiting enzymes (e.g. $11 \beta$-hydroxylase) that convert progesterone to cortisol that become sporadically underwhelmed during rapid increases in cortisol secretion, with stress allowing some progesterone to be shuttled into circulation (Chrétien \& Seidah 1981).

Other mammalian adipose tissue can produce reproductive steroid hormones (through modification of sterols), which should be considered when interpreting steroid hormone data from blubber tissue (Siiteri 1987, Ahima \& Flier 2000, Fonseca-Alaniz et al. 2007). Localized hormone production could be contributing to the measured levels in the blubber, though it is unknown if this specialized form of adipose tissue also produces steroid hormones. Given the large changes associated with pregnancy, we can be certain that circulating progesterone from the ovaries does accumulate in the blubber; however, it is quite plausible that at least some of the measured hormone is also locally derived.

\section{Urine progesterone}

Though urine levels of progesterone have not been reported previously in any cetacean, the progesterone metabolite, pregnanediol-3 alpha-glucuronide (PDG), has been measured in several odontocete species (Walker et al. 1988, Kjeld 2001, Robeck et al. 2004, 2005). There appears to be a strong relationship between urine progesterone and PDG, suggesting a relatively simple, though crude, transformation that links the 2 values (Stanczyk et al. 1997, Falk et al. 1999). The urine progesterone values were similar to other mammals (Herrick et al. 2000, Khan et al. 2008) and comparable to the transformed PDG values reported in other cetaceans (Robeck et al. 2004, 2005). Urine data was available for only 2 demographic groups in the present study: immature males and immature females. We found no significant difference between them, an expected result given that these 2 groups have relatively similar sexual endocrinology at this developmental stage.

\section{Relationships of progesterone levels in the different sample matrices}

One difficulty with the present study was that though many individuals were represented, the sample set was largely skewed in age (as judged by specimen length and corpora count in females) due to the selective nature and major logistical challenges of the subsistence hunt and the associated in-field research sampling. The subset of whales successfully landed during the harvest represent disproportionately smaller, younger animals (a hunter preference), yielding a sample set containing few mature individuals. Moreover, among the larger animals that were represented, few yielded all 3 sample matrices; thus, the comparisons between the matrices were largely derived from immature animals. Nonetheless, a number of important findings were revealed in the present study that may help delineate the basic dynamics of progesterone levels in different tissues.

When examining the serum and blubber progesterone levels, we found a large range of progesterone values in both matrices, with pregnant females at the high end and non-pregnant females at the low end of the range. Although we found a strong relationship between serum and blubber progesterone concentrations when values from all animals were used in the regression analysis, there was no significant concordance when the pregnant females were removed from the analysis. This is likely owing to the very different temporal fluctuations in progesterone concentrations in pregnant versus non-pregnant animals. In non-pregnant animals, significant fluctuations are associated with pulsatile progesterone production (Wuttke et al. 1998, Virolainen et al. 2005) for daily upkeep of basal levels (progesterone is needed as a precursor for most other steroid hormones). Within a 
particular day, relative serum progesterone levels often fluctuate greatly for a number of reasons, including the non-continuous pulsatile production of progesterone in gonadal tissue and adrenal glands that is released into the serum (Wuttke et al. 1998). Blubber is a peripheral tissue, some distance from these progesterone-producing tissues, and likely accumulates progesterone via passive diffusion from the serum (Deslypere et al. 1985). Thus, the concentration variation within the blubber is likely dampened compared with the variation within the serum throughout a given day. However, the increase in progesterone production during pregnancy is orders of magnitude larger than the daily fluctuations in the basal levels. The magnitude and duration of gestational progesterone production would allow the concentrations in blubber to equilibrate with those in serum, producing the strong relationship we observe between the matrices when both pregnancy states are analyzed together. Thus, regression analyses that include both pregnancy states are more indicative of concordance over long periods (weeks to months), and those that examine just 1 pregnancy state (in this case, just non-pregnant animals because there were too few samples to do the same analysis in only pregnant individuals) are more indicative of shorter-term dynamics (hours to days). Consequently, our findings suggest strong statistical concordance between serum and blubber progesterone over the long term and little to none over the short term.

Also of note in the blubber/serum progesterone regression analyses were the anomalous values. Two individuals had very high levels of progesterone in the blubber but not in the serum; i.e. high blubber/ serum progesterone ratios $>80$. Both were female; one had little associated reproductive information. The other showed signs of giving birth just prior to the harvest: her uterus was distended and nipples were protruding, and she had a small corpus luteum consistent in size with regression stage. The measured blubber/serum progesterone values of this individual substantially deviated from the modeled regression line. The blubber progesterone value for this individual was 50-fold higher than the median levels seen in non-pregnant/immature females, yet the serum level was close to levels seen in non-pregnant females (only 3-fold higher than the median). This suggests that progesterone levels in serum decrease faster than those in the blubber. However, it appears the decrease in the blubber is not too protracted, as the blubber value in this recently pregnant animal was already $1 / 42$ that of the mean pregnant concentration.
One of our goals was to delineate the relative timing of progesterone flow from production into each of these matrices. We ultimately want to know which matrix would receive the peak in progesterone concentration first, second, and third after a bolus of progesterone is produced. Though the present study was not designed to monitor the actual progression of these peaks in progesterone concentration (a very difficult endeavor with cetaceans, especially those in the wild), there are potential clues among the data. By examining the regression analyses from nonpregnant animals, we can formulate a model of the relative dynamics of progesterone concentration in each of the matrices that is consistent with these regression results. Again, serum and blubber progesterone did not have a statistically significant relationship with each other; however, urine progesterone did vary significantly with each of the other matrices. That suggests that urine progesterone is, on average, the middle or second matrix to receive the signal. Blood is clearly the first matrix to capture the peak wave of progesterone, and therefore, we assume then that blubber is the last; i.e. the time lag from production to peak signal is greatest in the blubber and least in the blood.

\section{CONCLUSION}

To our knowledge, these are among the first reported progesterone values from bowhead serum and the very first reported from bowhead blubber and urine samples. These values are important as we (1) continue establishing a baseline library of endocrine information from which we can compare in future studies and (2) begin comparing hormone values across multiple matrices such that we might be able to estimate, from the hormone levels in one matrix, the corresponding levels in the other matrices. The findings from the present study delineate a model of progesterone signal dynamics in these 3 tissues (serum, blubber, and urine) and demonstrate the utility of blubber progesterone as a useful tissue for assessing pregnancy state in bowhead whales. This will be especially important in efforts to use projectile biopsies to non-lethally assess the reproductive and health condition of free-ranging cetaceans.

Acknowledgements. We gratefully acknowledge the Barrow Whaling Captains Association and the Alaska Eskimo Whaling Commission for allowing us to sample their whales. G. Serra-Valente provided excellent archival and data support. We thank W. Perryman and S. Chivers for their help and sagacious input during the preparation of this manuscript. 


\section{LITERATURE CITED}

Ahima RS, Flier JS (2000) Adipose tissue as an endocrine organ. Trends Endocrinol Metab 11:327-332

> Amaral RS (2010) Use of alternative matrices to monitor steroid hormones in aquatic mammals: a review. Aquat Mamm 36:162-171

> Andersen ML, Tufik S (2006) Does male sexual behavior require progesterone? Brain Res Rev 51:136-143

> Atkinson S, Combelles C, Vincent D, Nachtigall P, Pawloski J, Breese M (1999) Monitoring of progesterone in captive female false killer whales, Pseudorca crassidens. Gen Comp Endocrinol 115:323-332

> Birukawa N, Ando H, Goto M, Kanda N and others (2005) Plasma and urine levels of electrolytes, urea and steroid hormones involved in osmoregulation of cetaceans. Zool Sci 22:1245-1257

- Budge SM, Springer AM, Iverson SJ, Sheffield G, Rosa C (2008) Blubber fatty acid composition of bowhead whales, Balaena mysticetus: implications for diet assessment and ecosystem monitoring. J Exp Mar Biol Ecol 359:40-46

> Chrétien M, Seidah NG (1981) Chemistry and biosynthesis of proopiomelanocortin. Mol Cell Biochem 34:101-127

> Cooper C, Evans ACO, Cook S, Rawlings NC (1995) Cortisol, progesterone and beta-endorphin response to stress in calves. Can J Anim Sci 75:197-201

> Deslypere JP, Verdonck L, Vermeulen A (1985) Fat tissue: a steroid reservoir and site of steroid metabolism. J Clin Endocrinol Metab 61:564-570

> Falk RT, Gail MH, Fears TR, Rossi SC and others (1999) Reproducibility and validity of radioimmunoassays for urinary hormones and metabolites in pre- and postmenopausal women. Cancer Epidemiol Biomarkers Prev 8:567-577

- Fonseca-Alaniz MH, Takada J, Alonso-Vale MIC, Lima FB (2007) Adipose tissue as an endocrine organ: from theory to practice. J Pediatr (Rio de Janeiro) 83:S192-S203

George JCC, Zeh J, Suydam R, Clark C (2004) Abundance and population trend (1978-2001) of western Arctic bowhead whales surveyed near Barrow, Alaska. Mar Mamm Sci 20:755-773

> George JC, Follmann E, Zeh J, Sousa M, Tarpley R, Suydam R, Horstmann-Dehn L (2011) A new way to estimate the age of bowhead whales (Balaena mysticetus) using ovarian corpora counts. Can J Zool 89:840-852

- Hamudikuwanda H, Gallo G, Block E, Downey BR (1996) Adipose tissue progesterone concentrations in dairy cows during late pregnancy and early lactation. Anim Reprod Sci 43:15-23

> Herrick JR, Agoramoorthy G, Rudran R, Harder JD (2000) Urinary progesterone in free-ranging red howler monkeys (Alouatta seniculus): preliminary observations of the estrous cycle and gestation. Am J Primatol 51:257-263

> Hillbrand FW, Elsaesser F (1983) Concentrations of progesterone in the backfat of pigs during the estrous cycle and after ovariectomy. J Reprod Fertil 69:73-80

> Hogg CJ, Vickers ER, Rogers TL (2005) Determination of testosterone in saliva and blow of bottlenose dolphins (Tursiops truncatus) using liquid chromatography-mass spectrometry. J Chromatogr B 814:339-346

Kellar NM, Trego ML, Marks CI, Dizon AE (2006) Determining pregnancy from blubber in three species of delphinids. Mar Mamm Sci 22:1-16

Kellar NM, Trego ML, Marks CI, Chivers SJ, Danil K, Archer
FI (2009) Blubber testosterone: a potential marker of male reproductive status in short-beaked common dolphins. Mar Mamm Sci 25:507-522

> Khan A, Berger RG, Decatanzaro D (2008) The onset of puberty in female mice as reflected in urinary steroids and uterine/ovarian mass: interactions of exposure to males, phyto-oestrogen content of diet, and ano-genital distance. Reproduction 135:99-106

> Kjeld M, Sigurjonsson J, Arnason A (1992) Sex hormone concentrations in blood serum from the North Atlantic fin whale (Balaenoptera physalus). J Endocrinol 134: 405-413

Kjeld M (2001) Concentrations of electrolytes, hormones, and other constituents in fresh postmortem blood and urine of fin whales (Balaenoptera physalus). Can J Zool 79:438-446

Kjeld M, Vikingsson GA, Alfredsson A, Olafsson O, Arnason A (2003) Sex hormone concentrations in the blood of sei whales (Balaenoptera borealis) off Iceland. J Cetacean Res Manag 5:233-240

> Kjeld M, Alfredsson A, Olafsson O, Tryland M, Christensen I, Stuen S, Arnason A (2004) Changes in blood testosterone and progesterone concentrations of the North Atlantic minke whale (Balaenoptera acutorostrata) during the feeding season. Can J Fish Aquat Sci 61:230-237

Koski WR, Davis RA, Miller GW, Withrow DE (1993) Reproduction. In: Burns JJ, Montague JJ, Cowles CJ (eds) The bowhead whale. Society for Marine Mammology, Lawrence, KS, p 239-274

Manly BFJ (1991) Randomization and Monte Carlo methods in biology. Chapman \& Hall, London

Mansour AAH, McKay DW, Lien J, Orr JC, Banoub JH, Oien N, Stenson G (2002) Determination of pregnancy status from blubber samples in minke whales (Balaenoptera acutorostrata). Mar Mamm Sci 18:112-120

> Noren DP, Mocklin JA (2012) Review of cetacean biopsy techniques: factors contributing to successful sample collection and physiological and behavioral impacts. Mar Mamm Sci 28:154-199

Pérez S, García-López A, De Stephanis R, Giménez J and others (2011) Use of blubber levels of progesterone to determine pregnancy in free-ranging live cetaceans. Mar Biol 158:1677-1680

Pineda MH (2003) Female reproductive system. In: Pineda MH, Dooley MP (eds) McDonald's veterinary endocrinology and reproduction. Iowa State Press, Ames, IA, p 283-340

Reese CS, Calvin JA, George JC, Tarpley RJ (2001) Estimation of fetal growth and gestation in bowhead whales. J Am Stat Assoc 96:915-923

> Robeck TR, Schneyer AL, McBain JF, Dalton LM, Walsh MT, Czekala NM, Kraemer DC (1993) Analysis of urinary immunoreactive steroid metabolites and gonadotropins for characterization of the estrous cycle, breeding period, and seasonal estrous activity of captive killer whales (Orcinus orca). Zoo Biol 12:173-187

> Robeck TR, Steinman KJ, Gearhart S, Reidarson TR, McBain JF, Monfort SL (2004) Reproductive physiology and development of artificial insemination technology in killer whales (Orcinus orca). Biol Reprod 71:650-660

> Robeck TR, Steinman KJ, Yoshioka M, Jensen E and others (2005) Estrous cycle characterisation and artificial insemination using frozen-thawed spermatozoa in the bottlenose dolphin (Tursiops truncatus). Reproduction 129:659-674

Rolland RM, Hunt KE, Kraus SD, Wasser SK (2005) Assessing reproductive status of right whales (Eubalaena 
glacialis) using fecal hormone metabolites. Gen Comp Endocrinol 142:308-317

Rolland RM, Hamilton PK, Kraus SD, Davenport B, Gillett RM, Wasser SK (2006) Faecal sampling using detection dogs to study reproduction and health in North American right whales (Eubalaena glacialis). J Cetacean Res Manag 8:121-125

Rosa C, Blake JE, Mazzaro L, Hoekstra P, Ylitalo GM, O'Hara TM (2007a) Vitamin A and E tissue distribution with comparisons to organochlorine concentrations in the serum, blubber and liver of the bowhead whale (Balaena mysticetus). Comp Biochem Physiol B Biochem Mol Biol 148:454-462

Rosa C, O'Hara TM, Hoekstra PF, Refsal KR, Blake JE (2007b) Serum thyroid hormone concentrations and thyroid histomorphology as biomarkers in bowhead whales (Balaena mysticetus). Can J Zool 85:609-618

Rosa C, Blake JE, Bratton GR, Dehn LA, Gray MJ, O'Hara TM (2008) Heavy metal and mineral concentrations and their relationship to histopathological findings in the bowhead whale (Balaena mysticetus). Sci Total Environ 399:165-178

Siiteri PK (1987) Adipose tissue as a source of hormones. Am J Clin Nutr 45:277-282

Stanczyk FZ, Gentzschein E, Ary BA, Kojima T, Ziogas A, Lobo RA (1997) Urinary progesterone and pregnanediol. Use for monitoring progesterone treatment. J Reprod Med 42:216-222

Suzuki T, Mogoe T, Asada M, Miyamoto A and others (2001)

Editorial responsibility: David Hodgson,

University of Exeter, Cornwall Campus, UK
Plasma and pituitary concentrations of gonadotropins (FSH and LH) in minke whales (Balaenoptera acutorostrata) during the feeding season. Theriogenology 55: 1127-1141

Temte JL (1991) Use of serum progesterone and testosterone to estimate sexual maturity in Dall's porpoise Phocoenoides dalli. Fish Bull 89:161-166

Virolainen JV, Love RJ, Tast A, Peltoniemi OAT (2005) Plasma progesterone concentration depends on sampling site in pigs. Anim Reprod Sci 86:305-316

Wagner CK (2006) The many faces of progesterone: a role in adult and developing male brain. Front Neuroendocrinol 27:340-359

Walker LA, Cornell L, Dahl KD, Czekala NM and others (1988) Urinary concentrations of ovarian steroid hormone metabolites and bioactive follicle-stimulating hormone in killer whales (Orcinus orca) during ovarian cycles and pregnancy. Biol Reprod 39:1013-1020

West KL, Atkinson S, Carmichael MJ, Sweeney JC, Krames B, Krames J (2000) Concentrations of progesterone in milk from bottlenose dolphins during different reproductive states. Gen Comp Endocrinol 117:218-224

Wuttke W, Theiling K, Hinney B, Pitzel L (1998) Regulation of steroid production and its function within the corpus luteum. Steroids 63:299-305

Yoshioka M, Okumura T, Aida K, Fujise Y (1994) A proposed technique for quantifying muscle progesterone content in minke whales (Balaenoptera acutorostrata). Can J Zool 72:368-370

Submitted: November 21, 2012; Accepted: August 13, 2013 Proofs received from author(s): October 29, 2013 